\title{
Forma y supraforma
}

Por: Leonardo Comba

Docente MT, programa de Diseño Gráfico

Areandina, sede Bogotá.

En la ejecución de su oficio, el comunicador visual "informa”, esto es, le da forma a lo informe, a lo que aún no tiene forma, mediante el uso consciente e intencionado del lenguaje visual. Evidentemente debe preexistir una información de base organizada y coherente, definida desde el uso adecuado del lenguaje alfabético, oral o escrito, un discurso específico que se debe "configurar", lo cual significa precisamente "dar determinada forma a algo" (RAE, 2017).

Según el criterio estricto y concreto de Wucius Wong “las formas son contornos compactos y positivos que ocupan un espacio y se diferencian del fondo" (1995, p.138) y relaciona el concepto con "todo lo que pueda ser visto" (p.43) e identificado. En este sentido, ubica la forma como el principal elemento visual, que, según su clasificación, contiene y en algunos casos determina a los demás elementos visuales (tamaño, color y textura) y de relación (dirección y posición), diferenciándolo de los elementos conceptuales, deducibles pero no perceptibles (punto, línea, plano y volumen), que a su vez se convierten en formas cuando pasan a ser visibles y verificables. 


\section{COMUNICACIÓN \\ VISUAL \\ Elemento \\ smtitot \\ Configurar}

\section{"El diseño cubre exigencias prácticas"}

Esta clasificación de los componentes fundamentales del lenguaje visual, enfocados como elementos del diseño, se ha constituido en una herramienta muy útil para entender la imagen desde la reflexión académica y práctica. Wong define el diseño como "un proceso de creación visual con un propósito. A diferencia de la pintura y de la escultura, que son realización de las visiones personales de un artista, el diseño cubre exigencias prácticas" (2014, p.41). Pero es precisamente en el contexto del arte donde se pueden abarcar implicaciones de este concepto que trasciendan lo visible y verificable, sin necesariamente entrar en los terrenos definidos por el pensamiento occidental como especulativos. 


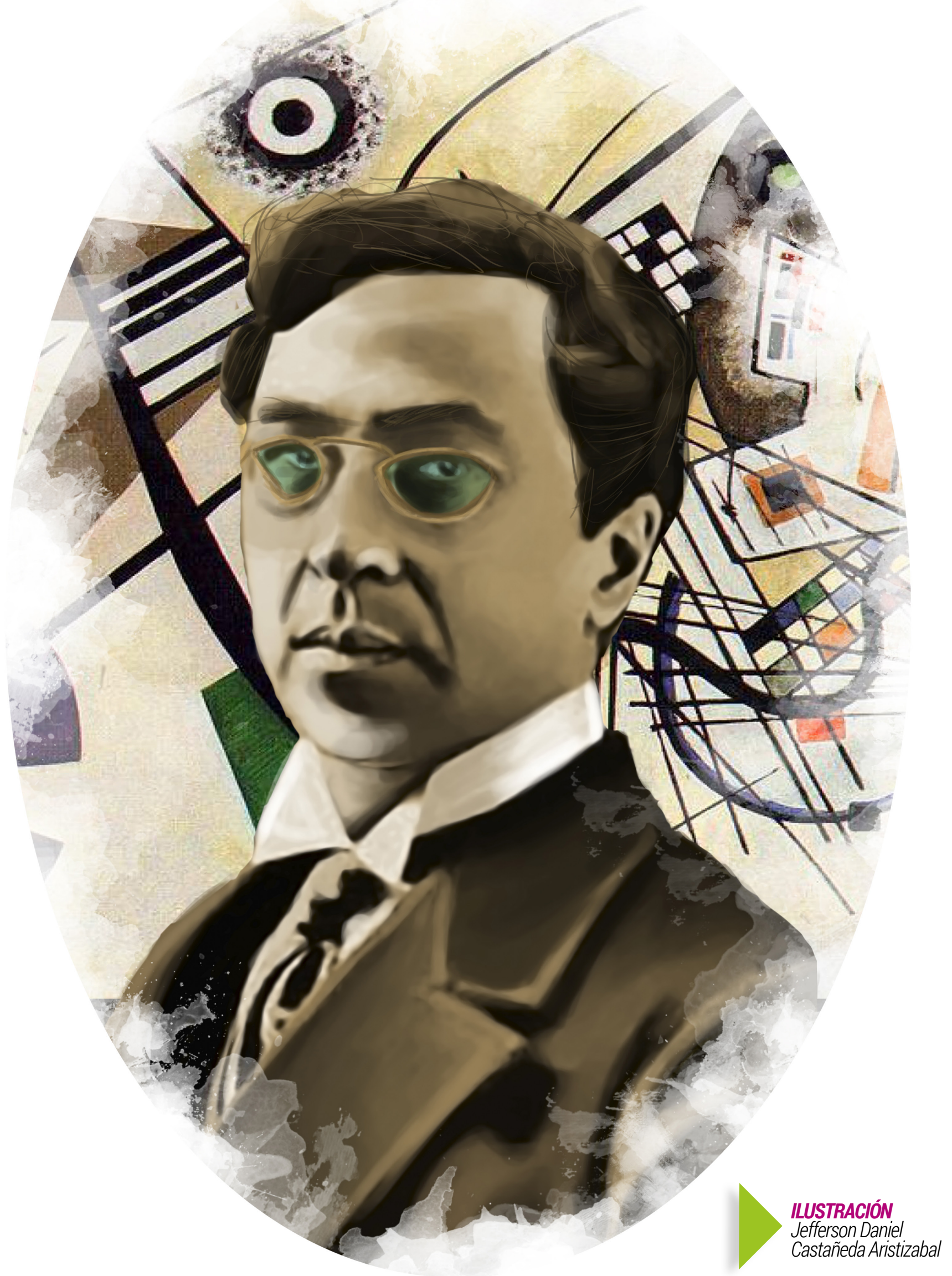


En los inicios del siglo XX, junto a la irrupción del arte abstracto moderno en occidente y constituyéndose como propiciadores de la aparición de la profesión del diseño, algunos artistas reflexionan sobre el tema de la forma y el lenguaje de las imágenes. En sus clásicas obras De lo espiritual en el arte, publicada en 1911 y más adelante en Punto y línea sobre el plano, de 1926, Vassily Kandinsky destaca el gran potencial que tienen los elementos visuales principalmente en la pintura, desde una perspectiva que va más allá de lo racional positivista, aproximándose a ellos desde lo intuitivo y considerando la dimensión de lo espiritual como primordial para la comprensión y la expresión de las artes visuales. Kandinsky percibe que la forma "aun cuando sea completamente abstracta y se reduzca a una forma geométrica, posee en sí misma su sonido interno, es un ente espiritual con propiedades identificables a ella" (1989, p.48).

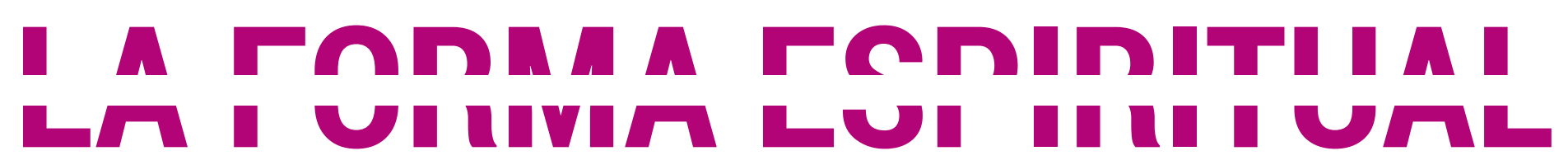


En contraste con lo anterior, Wong reconoce que sus propias interpretaciones "pueden parecer bastante rígidas y excesivamente simplificadas", relacionadas más con "un pensamiento sistemático y muy poco con la emoción y la intuición" (1995, p.41), aceptando, de todos modos, que los resultados de teorizaciones y categorizaciones son relativos y dependen del conjunto de lo estudiado por cada autor.

Entre estas dos polaridades esbozadas, vale decir la forma como elemento visual percibido y la forma como expresión y clave de lo informe, de lo no visible, o como lo menciona Manuel de Prada citando a Mario Perinola, entre "forma sensible (morfé en griego y forma en latín)" y "forma suprasensible (eidos en griego y species en latín)" (2008, p.25), adviene la forma simbólica, que precisamente se ocupa de representar aquello que no tiene forma, a diferencia del ícono o del índice, según la teoría de los signos de Charles S. Peirce (1986, p.46).

Aunque la categoría enunciada anteriormente como suprasensible puede hacer referencia a formas sugeridas de acuerdo a relaciones entre formas sensibles, a manera de estructura sentida aunque no percibida en una composición visual, el énfasis en este caso trasciende este sistema y se dirige más hacia la capacidad que puede tener una forma de abarcar lo inabarcable, precisamente el eidos, la gran idea, la esencia misma de las cosas, tal como se da en las teorías idealistas de la forma artística surgidas a partir de la concepción platónica: este mundo material sensible es solo una proyección, un reflejo, de un mundo ideal, suprasensible, que corresponde a la verdadera realidad (De Prada, 2008, p.27). 


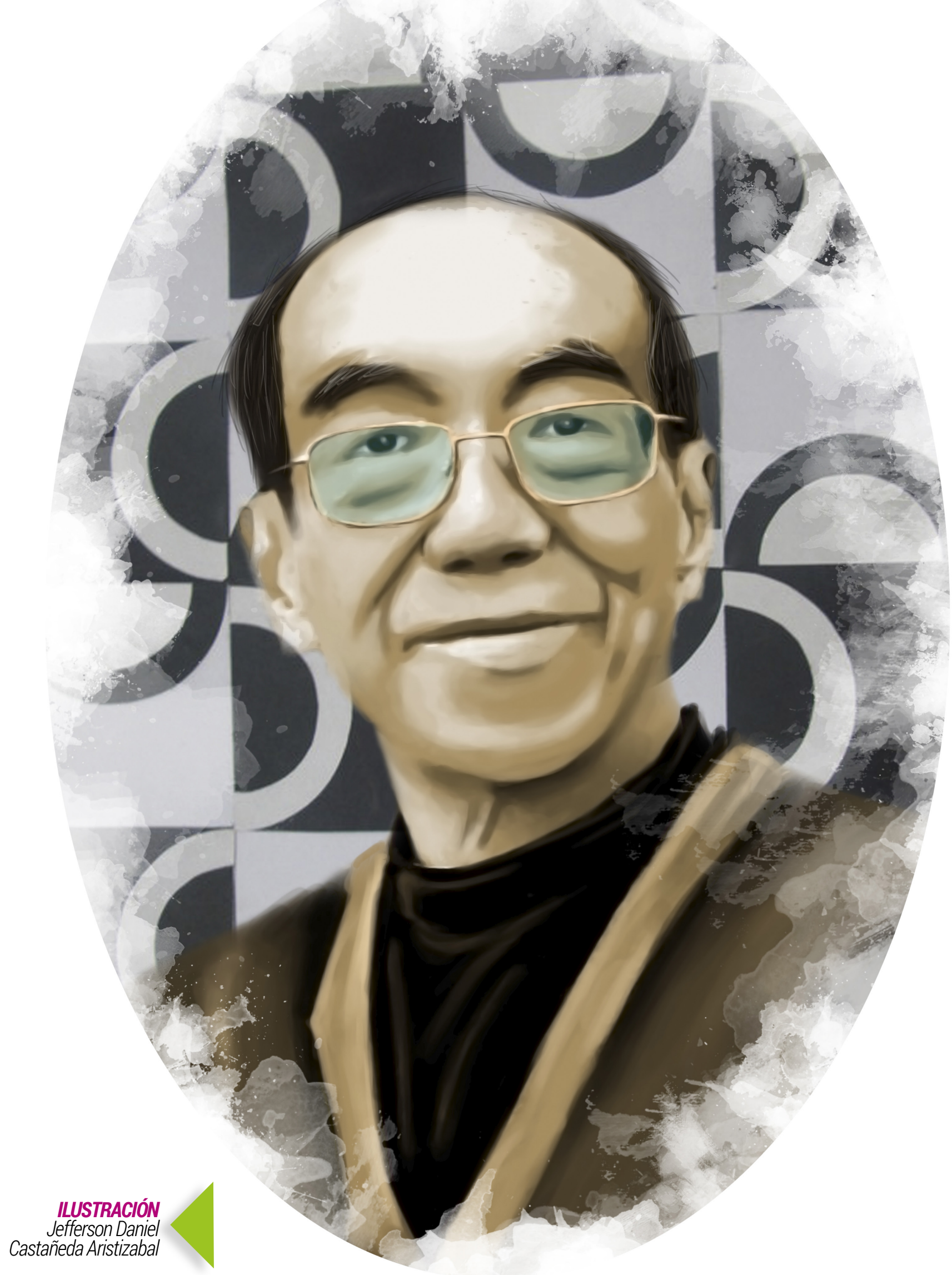




\section{La forma simbólica}

Teniendo en cuenta lo anterior, nos concentramos en el fenómeno del símbolo como portador de un inmenso potencial aglutinador de significado, de sentidos profundos, aún más de lo que podemos "imaginar". La imagen simbólica, según Mircea Eliade, evidencia "ciertos aspectos de la realidad que se niegan a cualquier otro medio de conocimiento" (1983, p.12), y que a su vez se relacionan con modelos arquetípicos plasmados en la mente humana en niveles tras o subconscientes. "Imágenes, símbolos, mitos, no son creaciones irresponsables de la psique; responden a una necesidad y llenan una función: dejar al desnudo las modalidades más secretas del ser" (Eliade, 1983, p. 12).

Tales estrategias de conocimiento codificado se han mantenido encapsuladas en el tiempo desde épocas inmemoriales a través de imágenes simbólicas imbuidas en cosmovisiones, mitologías y ritualidades propias de cada ancestralidad, de cada cultura y territorio, pero que en el fondo conservan la misma esencia. Según el artista e investigador Julio Amador (1999) "habitan en los niveles más profundos de la conciencia humana, son símbolos, figuras, imágenes que -bajo máscaras distintas-hablan con una misma voz", siendo el mito "la forma esencial en la cual se han conservado" (p.62).
En este sentido, retomando la comunicación visual como herramienta de nuestro propio conocimiento, y no de una mayor alienación, se hace necesario, además de lo aportado por las tendencias de pensamiento asumidas como de mayor relevancia y actualidad, considerar muy especialmente la perspectiva del pensamiento indígena americano, que en muchos casos coincide con las nociones de las más antiguas civilizaciones del mundo. Si se quiere profundizar la reflexión sobre el quehacer del diseñador y del artista visual en nuestro contexto, no deja de ser propicio mirar nuestras propias "supraformas", diseminadas a lo largo y ancho del territorio ancestral de donde provenimos, y que poco a poco van desapareciendo junto con el legado de hondo saber y conciencia que guardan.

\section{0lodmiz}




\section{$\underline{\text { Lista de Referencias }}$}

Amador, J. (1999). Mito, símbolo y arquetipo en los proceso de formación de la identidad colectiva e individual. Revista Mexicana de Ciencias Políticas y Sociales. 44 (176), 61-99. Recuperado de file://C:/Users/ USUARIO/Desktop/49010-134574-1-PB.pdf

De Prada, M. (2008). Arte y composición: el problema de la forma en el arte y la arquitectura. (Nobuko, Ed.) (Primera). Buenos Aires. Recuperado de http://site.ebrary.com.proxy.bidig.areandina.edu.co:2048/lib/bibliotecafuaasp/detail.action?docID=10504951

Eliade, M. (1983). Imágenes y símbolos. Ensayos sobre el simbolismo mágico-religioso. Madrid: Taurus.

Configurar (2017). En Real Academia Española. Recuperado de http:// dle.rae.es/?id=AFPjjk0

Kandinsky, V. (1989). De lo espiritual en el arte. (S. A. Premia editora de libros, Ed.) (Quinta edi). México. Recuperado de http://fundamentos1. bellasartesupr.org/Lecturas_files/Kandinsky-de-lo-espiritual-en-el-arte. pdf

Peirce, Ch. S. (1986). La ciencia de la semiótica. Buenos Aires: Nueva Visión.

Wong, W. (1995). Fundamentos del diseño. México: Ediciones G. Gili. Recuperado de https://pvunoserranogomez.files.wordpress. com/2013/05/fundamentos-del-disec3b1 o-wucius-wong.pdf 